\title{
Browsing and Plant Age Relationships to Winter Protein and Fiber of Big Sagebrush Subspecies
}

\author{
Carl L. Wambolt \\ Author is Professor of Range Science, Department of Animal and Range Sciences, Montana State University, Bozeman, MT 59717
}

\begin{abstract}
Plants of 3 big sagebrush subspecies, mountain big sagebrush (Artemisia tridentata ssp. vaseyana [Rydb.] Beetle), Wyoming big sagebrush (Artemisia tridentata ssp. wyomingensis Beetle and Young), and basin big sagebrush (Artemisia tridentata Nutt. ssp. tridentata) were sampled for crude protein and acid detergent fiber (ADF) content. The ADF was determined as an indication of energy content and digestibility. Crude protein and ADF levels were compared among the 3 taxa and between lightly and heavily browsed plants and young and mature plants within each subspecies. Current year growth collected in mid-January was sampled to coincide with the season of greatest ungulate browsing on big sagebrush. Crude protein for mountain big sagebrush (8.34\%) was less $(P \leq 0.05)$ than for Wyoming big sagebrush $(11.25 \%)$ and basin big sagebrush $(11.29 \%)$. All are well above the maintenance requirements of deer at $7.5 \%$ crude protein. The ADF levels between age and browse-use classes were not different $(P \leq 0.05)$ within any subspecies, although mountain big sagebrush generally had a lower ADF level than the other 2 subspecies. Wyoming big sagebrush was the only taxon with a crude protein difference $(1.2 \%)(P \leq 0.05)$ between age classes, although the difference is not biologically significant. Crude protein was not different between browse-use classes within any of the 3 taxa. Crude protein and digestibility do not indicate ungulate preference for these big sagebrush subspecies.
\end{abstract}

\section{Resumen}

Se muestrearon plantas de 3 subespecies de "Big sagebrush," "Mountain big sagebrush" (Artemisia tridentata ssp. vaseyana [Rydb.] Beetle), "Wyoming big sagebrush" (Artemisia tridentata ssp. wyomingensis Beetle and Young), y "Basin big sagebrush" (Artemisia tridentata Nutt. ssp. tridentata), para determinar su contenido de proteína cruda y fibra ácido detergente (ADF). El ADF se determinó como un indicador del contenido de energía y digestibilidad. Los niveles de proteína cruda y ADF se compararon entre las 3 taxas y entre plantas ligera y fuertemente ramoneadas y plantas jóvenes y maduras de cada subespecie. El crecimiento del año en curso, colectado a mediados de Enero, se muestreo para coincidir con la principal estación de ramoneo del "big sagebrush" por los grandes ungulados. El contenido de proteína cruda del "mountain big sagebrush" $(8.34 \%)$ fue menor que el del $(P \leq 0.05)$ "Wyoming big sagebrush" (11.25\%) y el del "basin big sagebrush" (11.29\%), sin embargo, el contenido de proteína cruda de todas las subespecies estuvo arriba de los requerimientos para mantenimiento del venado que es de $7.5 \%$. Los niveles de ADF entre clases de edad de la planta y nivel de ramoneo no fueron diferentes $(P \leq 0.05)$ dentro de ninguna de las subespecies, aunque, el "mountain big sagebrush" generalmente tuvo niveles de ADF menores que las otras 2 subespecies. El "Wyoming big sagebrush" fue el único taxón con diferencias en el contenido de proteína cruda $(1.2 \%)(P \leq 0.05)$ entre clases de edad de la planta, pero la diferencia biológicamente no es significativa. La proteína cruda no fue diferente entre clases de ramoneo en ninguna de la 3 taxas. El contenido de proteína cruda y digestibilidad no indican preferencia de los ungulados por estas subespecies de "big sagebrush."

Key Words: Artemisia tridentata, winter range, browse-use class, age class

\section{Introduction}

The value of big sagebrush (Artemisia tridentata Nutt.) as forage for a variety of native fauna is well documented (Welch and McArthur 1979a, 1979b; Striby et al 1987; Wambolt 1996; Welch 1999). Three subspecies, mountain big sagebrush (Artemisia tridentata ssp. vaseyana [Rydb.] Beetle), Wyoming big sagebrush (Artemisia tridentata ssp. wyomingensis Beetle and Young), and basin big sagebrush (Artemisia tridentata Nutt. ssp. tridentata) have been found to contain high levels of protein (Sheehy 1975; Welch and McArthur 1979b; Kelsey et al 1982), to be highly digestible (Welch and Pederson 1981; Striby et al 1987), and to be relished as forage by wildlife (Welch et al

Correspondence: Dr Carl Wambolt, Dept of Animal and Range Sciences, Montana State University, Bozeman, MT 59717. Email: cwambolt@montana.edu

Manuscript received 6 October 2002; manuscript accepted 4 August 2004.
1981, 1983; Welch and McArthur 1986; Wambolt 1996; Connelly et al 2000).

The relationships between protein level and browsing histories of individual sagebrush plants of the above-mentioned taxa have not been previously resolved. Conjecture has often been contradictory as to possible cause-and-effect relationships. The research questions posed are: 1) Does a higher initial protein level in a plant result in its being subsequently more heavily browsed?, or 2) Does a difference in browsing level between 2 plants result in a subsequent difference in protein levels? In the same manner, conjecture is often made regarding the relationship of plant age to protein level. Therefore, the hypotheses tested under natural conditions were: 1 ) Plants of 3 big sagebrush subspecies growing on a common site have equal crude protein and acid detergent fiber (ADF) levels, 2) Lightly and heavily browsed plants (long-term use) within each subspecies have equal crude protein and ADF levels, and 3) Young and mature plants within each subspecies have equal crude protein and ADF levels. 
Table 1. Crude protein (CP) and acid detergent fiber (ADF) among mature and young plants of 3 big sagebrush subspecies with standard deviations in parentheses.

\begin{tabular}{|c|c|c|c|c|}
\hline \multirow[b]{2}{*}{ Subspecies } & \multicolumn{2}{|c|}{ CP (\%) } & \multicolumn{2}{|c|}{$\operatorname{ADF}(\%)$} \\
\hline & Mature & Young & Mature & Young \\
\hline $\begin{array}{r}\text { Mountain big } \\
\text { sagebrush }\end{array}$ & $8.34^{a 1}(0.7)$ & $9.25^{\mathrm{a}}(0.3)$ & $24.79^{\mathrm{a}}(1.6)$ & $26.40^{\mathrm{a}}(1.0)$ \\
\hline $\begin{array}{c}\text { Wyoming big } \\
\text { sagebrush }\end{array}$ & $11.25^{b}(1.0)$ & $12.45^{c}(0.4)$ & $29.34^{c}(2.6)$ & $27.04^{\mathrm{abc}}(1.0)$ \\
\hline $\begin{array}{l}\text { Basin big } \\
\text { sagebrush }\end{array}$ & $11.29^{\mathrm{b}}(1.1)$ & $11.09^{b}(0.9)$ & $27.39^{\mathrm{bc}}(1.8)$ & $27.56^{\mathrm{bc}}(2.6)$ \\
\hline
\end{tabular}

'Means for individual nutrients differ $(P \leq 0.05)$ when followed by a different letter.

Although nutrient levels may vary with year and site effects, it is the relative differences in crude protein and ADF that are of importance in testing these hypotheses. Any relative differences in nutrients should be expected to be similar over time and other locations. This investigation provides these comparisons from an important mule deer and elk winter range that is unique in having the 3 taxa occur together naturally.

\section{Methods}

\section{Study Area}

The study site was located within the Gallatin National Forest near Gardiner, Montana. The area is a critical part of the Northern Yellowstone Winter Range (NYWR) (Houston 1982; Farnes 1991). The specific location (lat $45^{\circ} 2^{\prime} 53^{\prime \prime} \mathrm{N}$, long $110^{\circ} 40^{\prime} 8^{\prime \prime} \mathrm{W}$ ) is site number 2 used by Wambolt (1996) to study mule deer and elk foraging preference among the 3 big sagebrush taxa and black sagebrush (Artemisia nova Nels.). Elevation at the site is $1950 \mathrm{~m}$. Average annual precipitation is $412 \mathrm{~mm}$, half of which is received as snow (USDA 1981). Both the growing season and the 12 months prior to obtaining plant materials for nutrient analysis were near average for precipitation, receiving $97.5 \%$ of normal moisture. The area has an overstory of mountain big sagebrush, Wyoming big sagebrush, basin big sagebrush, and black sagebrush, and an understory dominated by bluebunch wheatgrass (Agropyron spicatum [Rydb.] Scribn.) and Idaho Fescue (Festuca idahoensis Elmer). The soils are mollisols from granite and limestone that have been strongly influenced by glacial scouring, morainal deposition, and outwash sediments (Wambolt and McNeal 1987). These processes have created a mosaic of microsites suitable for all 4 of the sagebrush taxa in nearly equal quantities.

\section{Sampling and Analysis}

To evaluate crude protein levels, 5 mature lightly browsed plants, 5 mature heavily browsed plants, and 5 young plants from each of the 3 big sagebrush subspecies were sampled $(n=45)$ (Welch and McArthur 1979b). Because the mature plants were among those studied for 10 years by Wambolt (1996), there was verification that the plants designated as falling into a heavy- or light-form class were really browsed in that manner. Wambolt (1996) recorded the leaders browsed on each plant for his preference study. Big sagebrush plants regarded as heavily browsed have numerous short thick branches in a compact form while lightly browsed plants have fewer, but longer slender branches in an open form. The young plants of all 3 taxa were located within the $30 \times 60 \mathrm{~m}$ browse cafeteria used by Wambolt (1996) and contained mature plants. The plants considered to be young had an average crown (from 4 intercepts) of $\leq 15 \mathrm{~cm}$.

Current year leaves and stems were harvested for later laboratory analysis of crude protein and ADF levels. This was the portion of the plant most likely to be browsed by wintering ungulates (Welch and McArthur 1979b; Wambolt 1996). These collections were made during mid-January 2001 because winter is the period of ungulate use on this range and is also the period of heaviest browsing on sagebrush taxa. Ten grams of the current year growth were collected and stored in ZipLoc ${ }^{10}$ plastic bags placed in an icebox for transporting.

Crude protein and ADF analyses were conducted by the Oscar O. Thomas Nutrition Center at Montana State University. Nitrogen (N) content was determined (AOAC 2000) for calculation of crude protein and ADF determination was made using the procedures described by Van Soest et al (1991). Levels of ADF relate directly to digestibility of the forage, as well as to energy level in forages (Reid et al 1988).

A two-way ANOVA with taxa and browse form class as the factors was conducted individually for crude protein and ADF. A second two-way ANOVA with taxa and plant age as the factors was also conducted in the same manner. Because taxa differences were expected from previous research, separating possible browse form class or age differences within each taxon was the goal. The Least Significant Difference (LSD) method $(P \leq 0.05)$ protected by a prior $F$ test $(P \leq 0.05)$ was used for comparing means (Snedecor and Cochran 1980). All differences discussed are significant at the $5 \%$ level,

\section{Results and Discussion}

\section{Taxa Protein Levels}

The midwinter crude protein levels found in the mature plants, by averaging the light- and heavy-form classes $(n=10$ per taxon) was $8.34 \%, 11.25 \%$, and $11.29 \%$ of total dry matter for mountain, Wyoming, and basin big sagebrush, respectively (Table 1). The protein level for mountain big sagebrush was significantly less $(P \leq 0.05)$ than for the other 2 subspecies. The same values for the young plants $(n=5$ per taxon) were $9.25 \%, 12.45 \%$, and $11.09 \%$, respectively (Table 1 ). All taxa protein values for the young plants were significantly different $(P \leq 0.05)$ from each other.

Other studies have reported somewhat higher crude protein values for these big sagebrush subspecies. Kelsey et al (1982) found $14.0 \%$ crude protein in mountain big sagebrush at other Montana locations. Their results were from November collections when protein is expected to be higher than in midJanuary. Although the differences for protein content between Kelsey et al (1982) and this study appears great, Welch and McArthur (1979b) reported a range of $8.5 \%$ to $14.4 \%$ in winter crude protein levels after reviewing 5 earlier reports. Welch and McArthur (1979b), in their own study, found crude protein levels in mountain big sagebrush and Wyoming big sagebrush of $11.1 \%$ and $11.8 \%$, respectively, which were significantly less $(P \leq 0.01)$ than the $14.5 \%$ for basin big 
sagebrush. Their study sampled the protein levels at the same mid-January period as did this study. Welch and McArthur (1979b) further demonstrated that considerable variation in crude protein level should be expected between various reports after they found significant genetic variation among different populations within a taxon that were transplanted to a uniform garden and sampled 7 and 8 growing seasons later. In addition to inherent genetic variation, site, seasonal, and year differences may also result in variation of crude protein levels.

\section{ADF Levels}

The ADF levels for all plants sampled are found in Tables 1 and 2. There were no significant $(P \leq 0.05)$ differences found between mature and young plants or between lightly or heavily browsed plants within any of the 3 subspecies. Mountain big sagebrush generally contained a lower ADF level than the other 2 subspecies of big sagebrush.

The ADF findings relate to quantity of cellulose and lignin found in the plants. Lower ADF figures indicate that forage has the potential to be both relatively higher in energy content and more digestible. Although prediction of digestibility by ADF alone has limitations, all of the ADF levels found in this study were low for midwinter. This concurs with the high digestibility found by Striby et al (1987) for these taxa.

Bluebunch wheatgrass, sampled in southwestern Montana 3 to 4 weeks earlier than the sagebrush in this study, had ADF levels ranging from $48.2 \%$ to $49.9 \%$ and crude protein from $2.87 \%$ to $3.18 \%$, which were averaged over a 3 -year study (Wambolt et al 1997). Thus, all the big sagebrush plants sampled in this study were nutritionally superior forage to bluebunch wheatgrass as measured by crude protein and ADF levels. This is logical as big sagebrush is an evergreen that conducts some photosynthesis during winter, therefore, winter foliage is metabolically active (Pearson 1975).

\section{Age Class Protein Levels}

Comparison of crude protein levels between young and mature plants within a subspecies varied among taxa (Table 1). Age class did not make a difference for mountain big sagebrush and basin big sagebrush. However, for Wyoming big sagebrush the young plants contained significantly $(P \leq 0.05)$ more crude protein $(1.2 \%)$ than the mature plants.

I conclude that there is no meaningful difference for herbivores in crude protein levels between the age classes of the 3 big sagebrush subspecies. The additional $1.2 \%$ crude protein for young Wyoming big sagebrush would result in an increase of $0.6 \%$ digestible protein (Striby et al 1987). It would be a rare circumstance when that level would be significant for wintering ungulates. This is especially true in this case as the crude protein levels for both age classes of Wyoming big sagebrush were well above the maintenance $(7.5 \%)$ and gestation $(9.0 \%)$ requirements for deer (Welch 1989). When the extremely low forage production of the younger, therefore smaller, plants is considered, the total protein available to ungulates is much less from the young plants on winter ranges (Wambolt et al 1994; Hoffman 1996).

Hoffman (1996) studied mountain big sagebrush in the same area as this study and determined that stands of older plants were more beneficial to ungulates because they produce more
Table 2. Crude protein (CP) and acid detergent fiber (ADF) among mature plants of 3 big sagebrush subspecies historically browsed either lightly or heavily with standard deviations in parentheses.

\begin{tabular}{|c|c|c|c|c|}
\hline \multirow[b]{2}{*}{ Subspecies } & \multicolumn{2}{|c|}{$\mathrm{CP}(\%)$} & \multicolumn{2}{|c|}{ ADF $(\%)$} \\
\hline & $\begin{array}{l}\text { Lightly } \\
\text { Browsed }\end{array}$ & $\begin{array}{c}\text { Heavily } \\
\text { Browsed }\end{array}$ & $\begin{array}{l}\text { Lightly } \\
\text { Browsed }\end{array}$ & $\begin{array}{l}\text { Heavily } \\
\text { Browsed }\end{array}$ \\
\hline $\begin{array}{r}\text { Mountain big } \\
\text { sagebrush }\end{array}$ & $8.24^{\mathrm{a} 1}(0.8)$ & $8.44^{\mathrm{a}}(0.7)$ & $25.52^{\mathrm{ab}}(1.9)$ & $24.07^{\mathrm{a}}(1.1)$ \\
\hline $\begin{array}{l}\text { Wyoming big } \\
\text { sagebrush }\end{array}$ & $11.25^{b}(1.1)$ & $11.24^{\mathrm{b}}(1.1)$ & $29.72^{d}(3.5)$ & $28.95^{\mathrm{cd}}(1.7)$ \\
\hline $\begin{array}{l}\text { Basin big } \\
\text { sagebrush }\end{array}$ & $11.09^{b}(1.1)$ & $11.49^{b}(1.1)$ & $28.03^{b c d}(1.0)$ & $26.75^{\mathrm{abc}}(2.4)$ \\
\hline
\end{tabular}

'Means for individual nutrients differ $(P \leq 0.05)$ when followed by a different letter.

forage than younger stands. This was true even in stands that had large amounts of dead crown from historically heavy browsing. Hoffman (1996) also noted that mature plants offer opportunity for both security and thermal cover, attributes that are especially important on ungulate winter range. These habitat values in combination with total available nutrients supplied by mature plants would always prove more beneficial to wintering animals than an increase of $<1 \%$ digestible protein from plants that already exceed native fauna requirements (Welch 1989).

\section{Browse Form Class Protein Levels}

The hypothesis that big sagebrush plants that have been historically browsed either lightly or heavily within each subspecies have equal crude protein levels was accepted. The protein levels between the 2 form classes (light and heavy) were not different within any of the 3 subspecies (Table 2).

These findings indicate that crude protein levels in big sagebrush plants neither attract browsing herbivores, nor do they change following a history of either light or heavy use. Therefore, observed utilization differences among subspecies and individual plants are best explained by differences in crude terpenoid content (Welch et al 1983; Personius et al 1987; Bray et al 1991). The higher levels of crude protein commonly found in basin big sagebrush and Wyoming big sagebrush compared to mountain big sagebrush does not result in more browsing on the former 2 subspecies (Scholl et al 1977; Sheehy and Winward 1981; Welch et al 1981, 1983; Welch and McArthur 1986; Wambolt 1996). Instead, the preference for mountain big sagebrush by ungulates is similar to that often displayed for certain plants within any of the big sagebrush subspecies. That is, crude protein does not have a primary role in determining preference as do certain terpenoids (Personius et al 1987; Bray et al 1991). In the same manner, relative digestibility among the subspecies does not influence their acceptance to ungulates. The most digestible subspecies (basin big sagebrush) is the least preferred and the least digestible subspecies (mountain big sagebrush) is the most preferred (Striby et al 1987; Wambolt 1996).

\section{Conclusions and Management Implications}

Sagebrush taxa comprise the most widespread vegetative types in the western United States. Many organisms with obligatory and near-obligatory relationships to sagebrush communities are focal points of political and management decisions on an ever- 
increasing basis (Wambolt et al 2002). Managers of sagebrush systems are often forced to make decisions based on faith of conventional wisdom. This study addresses often-encountered nutritional questions regarding management of sagebrush communities to improve wildlife habitat.

Crude protein and ADF levels may vary with year and site effects. However, the relative differences in these nutrients between taxa, age classes, and browse-use classes should remain consistent over time. These differences provided a basis for testing my hypotheses during a year of average precipitation. Either short-term or qualitative estimates of browsing histories would be speculative for determination of nutrient differences between lightly and heavily browsed plants. This was avoided by using browsing histories established over a decade-long companion study that quantified past browsing (Wambolt 1996).

January crude protein levels in the 3 big sagebrush subspecies studied all meet deer maintenance requirements (Welch 1989) regardless of plant age or past browsing. This investigation indicates that sagebrush crude protein levels will not increase by manipulating vegetative cover to favor early successional stages rich with young plants. Crude protein does not relate to past ungulate browsing levels on individual plants within the 3 big sagebrush subspecies. Also, mountain big sagebrush, the subspecies preferred by mule deer and elk at this site (Wambolt 1996), has the lowest crude protein content. In the same manner, the ADF levels found were not different among the 3 subspecies regardless of age or browse-use class. This indicates that energy content and digestibility are at best secondary to the sagebrush plant's crude terpenoids in determining animal preference (Bray et al 1991).

\section{Acknowledgments}

Bruce Welch, Bok Sowell, and Jan Bowman provided thoughtful reviews, and Harrie Sherwood assisted field work.

\section{Literature Cited}

[AOAC] Association of Official Analytical Chemists. 2000. Official methods of analysis (17th Ed.). Assoc. of Official Anal. Chemists. Gaithersburg, MD. $2200 \mathrm{p}$.

Bray, R. 0., C. L. Wambolt, and R. G. Kelsey. 1991. Influence of sagebrush terpenoids on mule deer preference. Journal of Chemical Ecology 17:20532062.

Connelly, J. W., M. A. Schroeder, A. R. Sands, and C. E. Braun. 2000. Guidelines to manage sage-grouse populations and their habitats. Wildlife Society Bulletin 28:967-985.

FARNES, P. E. 1991. A scaled index of winter severity. Proceedings of the Western Snow Conference; 12-15 April 1991; Juneau, AL. Fort Collins, CO: Colorado State University Press. p 134-137.

HoffMAN, T. L. 1996. An ecological investigation of mountain big sagebrush in the Gardiner basin [thesis]. Bozeman, MT: Montana State University. 84 p.

Houston, D. B. 1982. The northern Yellowstone elk, ecology and management. New York, NY: Macmillan Publishers. 474 p.

Kelsey, R. G., J. R. Stephens, and F. Shafizadeh. 1982. The chemical constituents of sagebrush foliage and their isolation. Journal of Range Management 35:617622.

PEARSON, L. C. 1975. Daily and seasonal patterns of photosynthesis in Artemisia tridentata. Journal of the Idaho Academy of Sciences 1975:11-19.
Personius, T. L., C. L. Wambolt, J. R. Stephens, and R. G. Kelsey. 1987. Crude terpenoid influence on mule deer preference for sagebrush. Journal of Range Management 40:84-88.

Reid, R. L., G. A. Jung, and W. V. Thayne. 1988. Relationships between nutritive quality and fiber components of cool season and warm season forages: A retrospective study. Journal of Animal Science 66:1275-1291.

Scholl, J. P., R. G. Kelsey, and F. Shafizadeh. 1977. Involvement of volatile compounds of Artemisia in browse preference by mule deer. Biochemical Systematics and Ecology 5:291-295.

Sheeny, D. P. 1975. Relative palatability of seven Artemisia taxa to mule deer and sheep [thesis]. Corvallis, OR: Oregon State University. 147 p.

Sheeny, D. P., and A. H. Winward. 1981. Relative palatability of seven Artemisia taxa to mule deer and sheep. Journal of Range Management 34:397-399.

SnedeCor, G. W., and W. G. Cochran. 1980. Statistical methods. Ames, IA: lowa State University Press.

Striby, K. D., C. L. Wambolt, R. G. Kelsey, and K. M. Havstad. 1987. Crude terpenoid influence on in vitro digestibility of sagebrush. Journal of Range Management 40:244-248.

[USDA] United States Department of Agriculture. 1981. Average annual precipitation. Bozeman, MT: Montana Soil Conservation Service.

Van Soest, P. J., J. B. Robertson, and B. A. Lewis. 1991. Methods for dietary fiber, neutral detergent fiber, and nonstarch polysaccharides in relation to animal nutrition. Journal of Dairy Science 74:3583-3597.

WamBoLt, C. L. 1996. Mule deer and elk foraging preference for 4 sagebrush taxa. Journal of Range Management 49:499-503.

Wambolt, C. L., W. H. Creamer, and R. J. Rossi. 1994. Predicting big sagebrush winter forage by subspecies and browse form class. Journal of Range Management 47:231-234.

Wambolt, C. L., M. R. Frisina, K. S. Douglass, and H. W. Sherwood. 1997. Grazing effects on nutritional quality of bluebunch wheatgrass for elk. Journal of Range Management 50:503-506.

Wambolt, C. L., A. J. Harp, B. L. Welch, N. Shaw, J. W. Connelly, K. P. Reese, C. L. Braun, D. A. Klebenow, E. D. McArthur, J. G. Thompson, L. A. Torell, and J. A. TANAKA. 2002. Conservation of the greater sage-grouse on public lands in the western U.S.: implications of recovery and management policies. Policy Analysis Center for Western Public Lands. Caldwell, ID: University of Idaho. 41 p.

Wambolt, C. L., and A. F. McNeal. 1987. Selection of winter foraging sites by elk and mule deer. Journal of Environmental Management 25:285-291.

WeLCH, B. L. 1989. Nutritive value of shrubs. In: C. M. McKell [ed.]. The biology and utilization of shrubs. San Diego, CA: Academic Press, Inc. p 405-424.

WeLCH, B. L. 1999. Add three more to the list of big sagebrush eaters. In: E. D. McArthur, W. K. Ostler, and C. L. Wambolt [compilers]. Proceedings of the Symposium on Shrubland Ecotones. Fort Collins, CO: United States Department of Agriculture. Forest Service Proc. RMRS-P-11. p 171-179.

WelCh, B. L., AND E. D. MCArthur. 1986. Wintering mule deer preference for 21 accessions of big sagebrush. Great Basin Naturalist 46:281-286.

Welch, B. L., E. D. McArthur, and J. N. Davis. 1981. Differential preference of wintering mule deer for accessions of big sagebrush and for black sagebrush. Journal of Range Management 34:409-411.

Welch, B. L., E. D. McArthur, and J. N. Davis. 1983. Mule deer preference and monoterpenoids (essential oils). Journal of Range Management 36:485-487.

Welch, B. L. And E. D. McArthur. 1979a. Feasibility of improving big sagebrush (Artemisia tridentata) for use on mule deer winter ranges, p 451-457. In. J. R. Goodin, and D. K. Northington (eds.), Arid land plant resources. Texas Tech Univ., Lubbock, TX.

WelCh, B. L., AND E. D. McArthur. 1979b. Variation in winter levels of crude protein among Artemisia tridentata subspecies grown in a uniform garden. Journal of Range Management 32:467-469.

WeLCH, B. L., AND J. C. PederSon. 1981. In vitro digestibility among accessions of big sagebrush by wild mule deer and its relationship to monoterpenoid content. Journal of Range Management 34:497-500. 